\title{
Cash To Accrual Accounting: One Nation's Dilemma
}

Geoffrey Tickell, Indiana University of Pennsylvania, USA

\begin{abstract}
Over the past three decades, there has been a slow but steady global movement undertaken by most governments to move from cash-based accounting to accrual-based accounting. This migration is the result of calls for greater accountability, increased transparency and more informed decision-making from the public sector. Questions remain regarding the implementation of accrual accounting within public sector organisations. This paper reports on an investigation into Fiji's attempt to use accrual accounting as its financial reporting format. Findings suggest that, due to the nation's low-skilled public service, high labor turnover and insufficient investment in capital equipment, undertaking the move to accrual accounting for this and similar developing nations require a different approach to that used by developing economies. This paper concludes with recommendations on how to effectively introduce accrual accounting in the public sector of developing nations.
\end{abstract}

Keywords: Government accounting, Accrual accounting, Fiji

\section{INTRODUCTION}

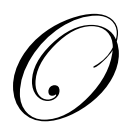

ver the past two decades, there has been a slow but steady global movement undertaken by most federal, state, and local governments to move from cash-basis accounting to accrual-basis accounting (see Boxall, 1998; Carlin, 2003). The governments of New Zealand and Australia led this process with European countries following soon after (e.g., Spain, Sweden and the United Kingdom). This migration from cashbasis accounting to accrual-basis accounting is the result of calls for greater accountability and transparency in the public sector (Dickinson, 2000). To this end, it is anticipated that over the next few years, all countries, including countries with developing economies, will change their accounting system to incorporate accrual accounting reports.

The Public Service Committee (PSC) of the International Federation of Accountants (IFAC) believes that accrual-based financial statements, rather than cash-based financial statements, provide the most relevant, reliable, comparable and useful information for users of financial information (Public Sector Committee, 2002). The PSC is encouraging all governments at all levels to move to accrual accounting and adopt International Public Sector Accounting Standards (IPSASs). The importance of governments improving their financial reporting has also been recognised by international and regional financial institutions such as the World Bank, the International Monetary Fund, the Asian Development Bank and the United Nations Development Program (Hepworth, 2003). These institutions also strongly encourage developing nations to make the migration. Often, the financial aid stemming from these financial institutions is contingent upon these countries improving their accounting information systems and adopting accrual accounting.

Given that this migration involves extensive work for governments, it is anticipated that developing nations with a relatively low-skilled civil service and insufficient infrastructure will experience difficulties implementing accrual accounting in the same way as their more highly skilled counterparts (e.g., Australia and New Zealand). Processes that are effective for countries with high-skilled laborforces might not be appropriate for those with lowskilled labor forces. Alternative methods need to be explored. 
This paper reports on an investigation undertaken within the public service of Fiji. This nation has attempted the move from cash to accrual accounting on two previous occasions (i.e., 1994 and 1998) and has put aside the project on each occasion. Once again, in 2005, this nation attempted the migration. On this attempt, however, the nation adopted a different approach to that used for the previous two unsuccessful attempts.

The present investigator undertook field research in 1994, 2004 and 2008 to determine the strategies adopted and the apparent success of each attempt. On the most recent visit, the public service of Fiji, despite many years of attempts, was still in its infancy stage in adopting accrual accounting. Regular military coups and general instability within the government were detrimental to progress in accrual accounting.

However, despite unstable government, the civil service of Fiji is taking small steps towards accrual accounting. Their planned strategy could be used as a template for other similar nations wanting to undertake such a migration but find the task too daunting.

\section{LITERATURE REVIEW}

Traditionally, the public sector has used cash accounting to present its financial transactions. Government financial reports, including annual budgets, were modified cash-based reports (Robinson, 2002). In contrast, the private sector has used accrual accounting to provide financial information to its stakeholders. Accrual accounting is regarded as providing more useful information for decision-making than cash accounting. The key difference between the two types of accounting (i.e., accrual and cash) lies in the timing as to when the transaction is recognised. With cash accounting, the transaction is recognised on the date the cash is received or disbursed. Under accrual accounting, the transaction is recognised on the date the income is earned or the expense is incurred. Thus, cash accounting focuses on cash receipts, cash payments and cash surpluses or deficits, while accrual accounting focuses on revenues, expenses and profits or losses. Therefore, net income reported by each method will not be the same amount. Proponents of the move to accrual accounting by governments are certain that accrual accounting will help people understand their government's finances better (Chase \& Triggs, 2001).

For the past twenty-to-thirty years, the public sector, encouraged by politicians with private enterprise backgrounds, have been moving to accrual accounting as its basis of financial reporting. Once the domain of macroeconomists, public sector accounting is now adhering to accounting standards (first implemented in the private sector). Today, accountants are far more involved in preparing the accounts and budgets of governments. Accrual accounting rather than cash accounting reports are being presented. The rationale for this change includes the corporatization of government departments and calls for greater accountability and transparency in the public sector (Guthrie, 1998).

The change to accrual accounting within a public sector organization rarely occurs in isolation. Often, the introduction of accrual accounting will be a relatively small component of a much largely reform project, and the nature of these wider reforms can often have an impact on the speed and the style of the transition to accrual accounting (Hepworth, 2003).

According to the Public Sector Committee of the International Federation of Accountants, the information contained in financial statements prepared on an accrual basis is useful both for accountability and decision-making (Public Sector Committee, 2002). Furthermore, accrual accounting provides information about the financial performance and position of public resources that cash accounting cannot (Rowles, 2004).

Accrual accounting provides information on revenues and expenses, including the impact of transactions where cash has not yet been received or paid (Public Sector Committee, 2002). Accrual accounting standards compel governments to acknowledge and plan for the payment of all recognized liabilities, not just borrowings. For example, all employee-related costs, including future retirement outlays, future annual leave payments, and probable sick-leave commitments are required to be recognised as long-term liabilities. Also, capital expenditure is treated differently. For example, in the case of a government purchasing a jet for their airforce, under cash accounting, the whole cost of the jet would be regarded as an expense in the year of purchase. However, accrual accounting concepts would apportion the cost of the jet over the expected life of the jet (e.g., 20 years). This concept of 
apportionment is called depreciation. Accrual accounting also requires infrastructure items such as roads and bridges to be valued and included as assets in government balance sheets.

Arguably, accrual accounting allows governments to take a more long-term view of their commitments and responsibilities than does cash accounting. Accrual accounting enables more informed decision making. Accrual budgeting, for example, enables the move away from cash inputs towards outputs and outcomes and provides additional information for governments to make decisions about resource allocations.

As noted, accrual accounting has long been the primary focus of private sector financial reports. To enable consistency and comparability among these private sector income statements and balance sheets, accounting standards have been developed and mandated. Once the jurisdiction of individual countries, these accounting standards are now becoming consistent internationally. From January 2001, Australia, New Zealand and the European Economic Community (EEC) produce financial statements using the same accounting standards (i.e., International Financial Reporting Standards, IFRS). The US retains jurisdiction over the accounting standards used in financial statements of US-based public companies under the Financial Accounting Standards Board (FASB). However, convergence between the two standards (IFRS \& FASB) is occurring. The Securities Exchange Commission (SEC) has a timeline for the adoption of IFRS for US public companies.

Accounting standards for the government sector are not progressing along a similar path as those taken by the private sector financial accounting standards boards. In the US, financial accounting standards for the government sector are developed by the Government Accounting Standards Board (GASB). This independent, private-sector, not-for-profit organization establishes and amends standards of financial accounting and reporting for US state and local governments. Governments and the accounting industry recognize the GASB as the official source of generally accepted accounting principles for these US governments (GASB, 2005).

At the international level, there are separate accounting standards for the public and private sector. International accounting standards (i.e., IFRS's) are designed for profit-seeking entities. The Public Sector Committee (PSC) of IFAC has issued a series of International Public Sector Accounting Standards (IPSAS) that modify IFRS's for the public sector. That is, IFRS's are used as foundation standards to which the PSC will add material to cover the not-for-profit sector. There are currently 20 IPSAS (IFAC, 2005). These standards are expected to apply to all public sector entities (including national, state and local government and their component entities) other than government business enterprises (which will comply with IFRS's).

In contrast, the public sectors of Australia and New Zealand have adopted sector-neutral accounting standards. The Australian Accounting Standards Board (AASB) has reconfirmed its commitment to developing sector-neutral standards. That is, current accounting standard setting in Australia and New Zealand reflects the view that generally accepted accounting principles are applicable to both the public and private sector. Although the IFRS's are intended for profit-seeking entities, the AASB and the Financial Reporting Standards Board of the Institute of Chartered Accountants of New Zealand have chosen to commit to developing sector-neutral standards. Hence, unlike other jurisdictions around the world, where there are separate accounting standards for the private sector and the government sector, Australian and New Zealand accounting standards mandate private sector accrual accounting standards to be applied to the government and not-for-profit sectors (Baskerville \& Pont Newby, 2002). Only three Australian Accounting Standards have been developed specifically for the Australian public sector: AAS27, AAS29, and AAS31. Furthermore, government entities that are not subject to these three accounting standards, such as government trading enterprises, are required to comply with all relevant IFRS's.

Governments across Australia have been required to produce general-purpose financial reports for the whole of government since 1999. Government Finance Statistics (GFS) framework, used by the Australian Bureau of Statistics to analyse budget results in Australia, has moved from cash to accrual accounting. However, the GFS and AASB frameworks treat certain transactions differently and produce significantly different bottom lines. For example, the GFS net lending bottom line does not include a cost for depreciation but instead includes cash capital expenditure. As expected, this has led to some confusion in the analysis of budget results (Robinson, 2002). While there are current moves to harmonise GFS and AASB's, there is substantial debate as to whether this is possible or even desirable. 
It should be noted that there are many dissenting voices questioning the benefits of governments adopting accrual accounting. Guthrie (1998) argues "the reality is that the accrual system of accounting is in most cases no better equipped to provide solutions ..... and may in fact result in the production of spurious and confusing data for users of financial reports" (p.15). The Government Accounting Office of the USA also suggests that the inclusion of accrual variables into government accounting financial reports will lead to, rather than resolve, reader confusion (see Guthrie, 1998).

Accrual accounting, while arguably successfully implemented in developed economies, is yet to be successfully integrated into the accounting systems of many developing economies. This is despite numerous attempts by some countries. It has been recognised by IFAC's Public Sector Committee (Public Sector Committee, 2002, p.19) that the factors that may influence the nature and speed of the migration to accrual accounting include:

- $\quad$ The system of government and the political environment of the nation

- Whether the reforms are focused solely on changing the reporting framework or encompassing other wider scale reforms

- Whether the changes are being driven from the "top down" or "bottom up"

- The current basis of accounting used by the entity, the capability of existing information system, and the completeness and accuracy of existing information, particularly in relation to assets and liabilities

- $\quad$ The basis of accounting to be used in the preparation of budget documents

- $\quad$ The level of political commitment to the adoption of accrual accounting, and

- $\quad$ The capacity and skills of the people and organizations responsible for implementing the changes.

Moreover, the OECD (OECD, 1993, p. 13) notes that:

The introduction of accrual accounting implies a requirement for substantial investment in management information systems in order to support ex-ante budgeting requirements and to support improved management practices. It requires a cultural change by managers within departments and agencies through an understanding and acceptance of how to use the additional information and of the potential benefits which it produces, and a commitment to change.

The requirement for large expenditure on infrastructure and the necessary institutional change can prove to be a huge obstacle for developing economies. According to Digitaki (2002), for Fiji, "the governments accounting system is at least 20 years old and follows the outdated cash-based accounting system". He continues, "Since the mid-1990's, strong calls have been made from some in the private sector to overhaul the system and replace it with a new one that is based on accrual accounting standards" It is apparent that, in this nation in 1994, the Finance Ministry responded by attempting to introduce accrual accounting, along with many other public sector reforms. According to the Auditor General's Report of that nation, "An Accrual Accounting Project Office (AAPO) was set up on 14 November 1994 after Cabinet had given approval to implement a full accrual accounting system. The introduction of accrual accounting in Government departments was needed to provide management with more efficient and accurate financial management information system than available on a cash basis" (see Jacobs, 2000).

At the time (i.e., 1994), the proposed implementation arrangements for the introduction of accrual accounting were:

- $\quad$ Migration in a two-stage process. In the first stage, three departments were to be selected for the pilot migration. These were Forestry, Finance, and Marine. The remaining departments were to migrate to accrual accounting in the second stage.

- The pilot departments were to aim at providing accrual budget information in March 1995 and complete the pilot migration by 1 January 1996.

- $\quad$ The remaining departments were to aim at providing accrual budget information in March 1996 and complete the pilot migration by 1 January 1997 .

- A project team of eight members (with four support staff) was established to work with external consultants. 
- $\quad$ The project team and the external consultants were to report to the Permanent Secretary for Finance and Economic Development, who was the Chairman of the Project Steering Committee.

However, after considerable effort and expense, the project was put aside when a change of government occurred as a result of the 1999 election. The Permanent Secretary for Finance advised the Public Accounts Committee that a major contributing factor to the projects failure was the absence of a commissioned manager to oversee the operations when the Accrual Accounting Project was implemented in 1994. According to the Auditor General, "the lack of accounting expertise in government led to additional expenses, particularly the need to outsource major accrual preparatory work" (Jacobs, 2000, p.iii).

With the overthrow of the 1999 government in 2002 (after a coup), the new Interim Administration recommenced the project. Despite another coup and regular interim governments, the government of Fiji is forging ahead with plans to migrate from cash to accrual accounting.

According to Fellow and Kelaher (1991) the accrual accounting concept is simple to understand, but difficult to implement. Indeed the task of implementing accrual financial accounting is invariably underestimated in the commercialisation process. The Treasury Board of Canada (see Public Sector Committee, 2002, p.45) has identified some key lessons learned from government organizations that have already converted to accrual accounting systems. These include:

- It is almost impossible to overestimate the amount of training required

- $\quad$ Staff turnover will occur during implementation

- Training is best when using actual data because it is more meaningful to those personnel being trained.

Furthermore, an early focus on accounting policies and standards is appropriate as these can impact on the subsequent requirements of information systems, training strategies and communication strategies.

Despite the increasing appeal of accrual accounting and its broad ranging implications for the role and functioning of public sector accounting systems, there has been comparatively little study of its application and consequences for the wider community (Guthrie, 1998). This is even more pertinent for developing countries. For these nations, are the rewards of the move to accrual accounting worth the effort and expense involved?

\section{RESEARCH METHOD}

The research methodology adopted for data collection involved semi-structured interviews with key proponents involved in the government's migration from cash to accrual accounting. The first series of interviews occurred in Fiji in 2004. The follow-up interviews were undertaken in 2008. Participants were from the Auditor General's office, the Finance Department, the Attorney General's Department, and the Lands Department. Interviews took approximately two-hours for each participant and, with their consent, were audio-taped. Transcripts were developed from the audiotapes to derive common themes.

Questions put to participants were based on the following general topics.

1. What was/is your involvement in the cash-to-accrual accounting project?

2. What is your opinion of how the project is going?

3. Why do you believe accrual accounting has not been successfully implemented yet?

4. Will the reports of the government follow accounting standards and, if so, which jurisdiction will those accounting standards originate from?

\section{RESULTS}

With regards to the slowness in implementing accrual accounting, four common themes were derived from the audio transcripts. 
1. Too much too soon: Generally, participants were of the opinion that, in the early attempts, the government attempted to change too much too soon. That is, wide-ranging public-service reforms were being undertaken in conjunction with the cash-to-accrual accounting migration. These included changing the role of Permanent Secretaries to that of Chief Executive Officers as well as putting the Chief Executive Officers onto performance-based contracts.

2. Incorrect software purchased: The overriding viewpoint from most participants was that the software purchased to implement the new financial management information system was too complex, too expensive and required too many system changes. The feeling the present investigator received during interviews was that, for the first attempt, the public service believed that all that was required to introduce accrual accounting was to purchase the appropriate hardware and software. Furthermore, that it was software problems that caused the accrual accounting project to fail on the first two occasions. One participant noted that "The government could have saved millions of dollars by getting programmers to write a tailor-made program rather than using an off-the-shelf program”.

3. Too much reliance on international consultants: On the first two occasions, an international accounting firm from Australia was engaged to manage the adoption of the new accounting system. This firm decided on the software to be introduced, trained key local personnel on how to use the software, and regularly flew in from Australia for trouble-shooting. However, the participants' opinions were that the consultants were too expensive (e.g., airfares, accommodation, living expenses and their daily consulting fee), the software was too large for a small nation, and that there was insufficient on-the-ground support. For example, one participant commented that "Consultants cost approximately \$2,000 per day. In addition, the government had to pay for airfares and cost of living allowances”. Moreover, at the end of the consulting engagement, most trained local personnel resigned from the public service to join the software company.

4. Low-skill base for public service accountants: It was openly stated by the majority of participants that this nation has insufficiently educated and trained personnel to effectively undertake the cash-to-accrual accounting migration. Wages are low (commencing at about \$8,000 per annum), skilled civil service staff resign for higher paid private sector employment, retirement occurs at 55 years, and potential incoming civil servants (e.g., accounting graduates) are attracted by the more attractive remuneration from the private sector or overseas (e.g., Australia, New Zealand, \& the US). These factors combine to cause the pool of civil service personnel with the required skills and knowledge being undersized. For example, several participants explained the predicament with the question, "Why should the graduates stay on when they can earn three to four times more overseas?" Although all participants hoped that the most recent endevor would be successful, not all participants were optimistic.

Since 2004, the accrual accounting project, now led by the Ministry of Finance of Fiji, is on a much smaller scale and far more focused than those previously attempted. The project's overall plan is as follows:

1. Appointment of one change management expert: The Ministry of Finance appointed one international consultant experienced in cash-to-accrual accounting migration. This person, rather than fly in from overseas as required, undertook to reside in the country for two years. His salary is being paid by the Asian Development Bank (ADB). His role is to manage and oversee the operations.

2. Tailor made training courses: The Ministry of Finance, in conjunction with the Department of Accounting at the nearby university, is using a tailor-made course of study to teach the small number of participants how to implement the accrual accounting migration. The partnership between the Ministry of Finance and the University was to exist for three years. Again, funding came from the ADB. A small number of selected employees within the Ministry of Finance would undertake the course. Upon completion of the course, the students would graduate with a Certificate qualification. The prospect of the course continuing after this time, to allow for more personnel to be trained, was uncertain.

3. Pilot project: The Ministry of Finance would undertake a pilot-project initially and would expand upon it depending upon the success of the pilot-project. Although no firm timelines were declared, it was felt that the pilot-project would take approximately two years, with expansion to other departments occurring over a three-to-five year period. 
4. Abide with international accounting standards: With regards to implementing generally accepted accounting standards, the Ministry of Finance would take guidance from Australia. It is noteworthy that the Australian professional accounting bodies adhere to the IFRS's and have not adopted the GASB standards or the IPSAS's.

5. Utilize existing software: The Ministry of Finance undertook to utilise the software that had been purchased for the first two attempts. The thinking by key personnel on this matter is that there has been a $\$ 25$ million investment in the software and it was felt that the accounting program was capable of handling the new range of transactions.

\section{DISCUSSION}

The migration from cash-based accounting reports to accrual-based accounting reports is far easier said than done. For countries such as Australia and New Zealand, despite their highly skilled and relatively well-paid public service, the transition has been quite difficult and there are many issues yet to be resolved. For example, what value should be placed on community assets and heritage assets and how should they account for and value BOOT (build, own, operate, transfer) projects. As noted, for developing economies with low-skilled and transient labor forces and out-of-date infrastructure, these difficulties are intensified. Irrespective of these issues, developing nations are also expected to, and are attempting to, move to accrual accounting. For many developing nations, their aid funds are linked to them modernising their accounting information systems and, by implication, adopting accrual accounting.

For Fiji, the project is continuing at a very slow pace. The size of the project has been down-sized considerably from the initial implementation. Personnel training is more structured and focused. The expertise is residing rather than visiting from overseas. The expertise will oversee the completion of the whole project rather than consult only on managing the software. Furthermore, managers of the change now appreciate that the move to accrual accounting involves substantially more than just changing the accounting software. However, vital questions still remain.

1. Will key personnel, after being trained in accrual accounting, leave for the local or overseas private sector for larger salaries and other benefits? Unless the public sector is able to meet private sector remuneration (which seems very unlikely for this small nation), high labor turnover of skilled personnel is likely to continue. It is noteworthy that governments of developed nations also experience difficulties in attracting and keeping highly skilled accounting personnel. They also depart for the more attractive remuneration of the private sector (Taylor, 2005).

2. Are the project leaders, once again, underestimating the amount of training that is required of personnel whose task it will be to implement accrual accounting procedures on a daily basis?

3. Is the government of this nation prepared to make a large investment into upgrading the required infrastructure (e.g., computer hardware)? An upgrade will be required for the proper accounting of assets and liabilities, asset management, and stronger internal control procedures. It is possible that the government of this nation might not be able to afford the investment required.

4. Will the public servants, not presently involved in the accrual accounting project, enthusiastically embrace the change that accrual accounting will bring and will they willingly undertake the required on-the-job training when the reforms reach their branch? Many of the public servants have been involved in accrual accounting training on the two previous occasions and will, most likely, be pessimistic about the future of another attempt.

With these difficulties expected, it is anticipated that, for this nation, it will take many years for the full migration from cash to accrual accounting to be complete. To the present investigator, the main questions to be answered are: "Is it worthwhile for this and other developing nations to adopt accrual accounting?" "Will the benefits outweigh the costs?" "Will the accrual accounting reports lead to better decision-making from government departments?" To be fair, these questions remain unanswered, not only for developing nations pursuing accrual accounting, but also for developed nations that have made the move. 


\section{AUTHOR INFORMATION}

Geoffrey Tickell, $\mathrm{Ph}$. D, CPA, is Associate Professor of Accounting at Indiana University of Pennsylvania. He holds a Bachelor of Education and a Graduate Diploma of Business (Accounting) from Deakin University, and a Doctorate from Monash University. He has taught higher education students for over 20 years. His research interests include government sector accounting and accounting education.

\section{REFERENCES}

1. Baskerville, R. F., \& Pont Newby, S. (2002). Due process failure in sector-neutral accounting standard setting. Financial Accountability \& Management, 18(1), 1-23.

2. Boxall, P. (1998). The revolution in government accounting. Australian CPA, 68(3), 18.

3. Carlin, T. M. (2003). Accrual accounting \& financial reporting in the public sector: Reframing the debate.

4. Carnegie, G. D., \& West, B. P. (2004). Making accounting accountable in the public sector.

5. Chase, B. W., \& Triggs, L. B. (2001). How to implement GASB Statement No. 34. Journal of Accountancy(November).

6. Dickinson, C. (2000). International Federation of Accountants. Accountancy SA, August(S1).

7. Digitaki, T. (2002). Accounting for whom? The Review, March 12-15.

8. Fellow, K., \& Kelaher, M. (1991). Managing the government the corporate way. Australian Accountant, 61(3), 20.

9. GASB. (2005). GASB at a glance. Retrieved December, 2005, 2005

10. Guthrie, J. (1998). Application of accrual accounting in the Australian public sector - rhetoric or reality. Financial Accountability \& Management, 14(1), 1.

11. Hepworth, N. (2003). Preconditions for successful implementation of accrual accounting in central government. Public Money \& Management.

12. IFAC. (2005). International Public Sector Accounting Standards Board. Retrieved December 2005, 2005

13. Jacobs, M. J. (2000). Report of the Auditor General of the Republic of the Fiji Islands Suva: Parliament of Fiji.

14. OECD. (1993). Accounting for what? The value of accrual accounting to the public sector. Paris: OECD.

15. Public Sector Committee. (2002). Transition to the accrual basis of accounting: Guidance for governments and government entities. New York: International Federation of Accountants.

16. Robinson, M. (2002). Financial control in Australian Government budgeting. Public Budgeting \& Finance, Spring, 80-93.

17. Rowles, T. (2004). Accrual accounting in the public sector: Its usefulness in economic decision making. Journal of Finance and Management in Public Services, 3(2).

18. Taylor, J. (2005). Recruiting university graduates for the public sector: An Australian case study. International Journal of Public Sector Management, 18(6), 514-533. 